\title{
PENGARUH PERAN KEPALA SEKOLAH DAN BUDAYA KERJA TERHADAP MOTIVASI BERPRESTASI GURU SEKOLAH DASAR DI KABUPATEN SEMARANG
}

\author{
Noor Miyono $^{a *}$, Erny Dewi Astuti ${ }^{a)}$ \\ a) Universitas PGRI Semarang, Semarang, Indonesia \\ *) e-mail korespondensi: noor.miyono@unpak.ac.id
}

riwayat artikel : diterima: 19 November 2019; direvisi: 27 Desember 2019; disetujui: 19 Januari 2020

\begin{abstract}
Abstrak. Penelitian ini bertujuan mengetahui (1) pengaruh peran kepala sekolah terhadap motivasi berperstasi guru. (2) pengaruh budaya kerja terhadap motivasi berprestasi guru (3) pengaruh peran kepala sekolah dan budaya kerja secara bersama-sama terhadap motivasi berprestasi guru. Populasi dalam penelitian ini guru SD Negeri Se-Kecamatan Susukan Kabupaten Semarang yang berjumlah 269 orang, sampel sebanyak 161 guru dengan menggunakan proportional randum sampling. Metode pengumpulan menggunakan kuesioner. Analisis data menggunakan analisis deskriptif, uji hipotesis yang terdiri dari regresi sederhana dan berganda dengan menggunakan program SPSS for Window Release 21. Temuan penelitian menunjukkan bahwa peran kepala sekolah berpengaruh signifikan terhadap motivasi berprestasi guru sebesar 34,8\%. Budaya kerja berpengaruh signifikan terhadap motivasi berprestasi guru sebesar $34,1 \%$, Peran kepala sekolah dan budaya kerja berpengaruh signifikan terhadap motivasi berprestasi guru SDN Kecamatan Susukan Kabupaten Semarang sebesar $44,8 \%$, dengan persamaan regresi $\hat{Y}=12,075+0.399 X_{1}+0.484 X_{2}$ sehingga semakin baik peran kepala sekolah dan budaya kerja maka motivasi berprestasi guru juga semakin meningkat.
\end{abstract}

Kata Kunci: peran; budaya kerja; motivasi berprestasi

\section{THE EFFECT OF THE ROLE OF THE SCHOOL HEAD AND WORK CULTURE ON THE ACHIEVEMENT OF BASIC SCHOOL TEACHERS MOTIVATION IN SEMARANG DISTRICT}

\begin{abstract}
This study to determine (1) the effect of the principal's role on teacher achievement motivation. (2) the influence of work culture on teacher achievement motivation (3) the effect of the principal's role and work culture together on teacher achievement motivation. The population in this study was 269 elementary school teachers in Susukan subdistrict, Semarang regency, a sample of 161 teachers using proportional sampling sampling. The collection method uses a questionnaire. Data analysis using descriptive analysis, hypothesis testing consisting of simple and multiple regression using the SPSS for Window Release 21 program The research findings show that the role of the principal has a significant effect on teacher achievement motivation by $34.8 \%$. Work culture has a significant effect on teacher achievement motivation by $34.1 \%$, the role of school principals and work culture has a significant effect on teacher achievement motivation in SDN Susukan Semarang regency by $44.8 \%$, with a regression equation $\hat{Y}=$ $12.075+0.399 \mathrm{X} 1+0.484 \mathrm{X} 2$. so the better the role of the principal and work culture, the teacher achievement motivation will also increase
\end{abstract}

Keywords: role: work culture; achievement motivation.

\section{PENDAHULUAN}

Sekolah berfungsi untuk memberikan pengetahuan, keterampilan dan membentuk sikap peserta didik. Sekolah menjadi salah tempat berlangsungnya proses kegiatan belajar mengajar, diharapkan dapat mencapai tujuan pendidikan membekali peserta didik agar memiliki tingkat kognitif, afektif dan psikomotorik yang berkembang baik sehingga para peserta didik menjadi sumberdaya manusia yang handal dan bertanggung jawab ditengah-tengah masyarakat, bangsa dan negara. Salah satu permasalahan pendidikan secara umum adalah rendahnya kualitas pendidikan khususnya pada kualitas pendidiknya. Berbagai usaha telah dilakukan untuk meningkatkan mutu pendidikan, misalnya peningkatan kompetensi guru melalui pelatihan, pengadaan buku dan alat pelajaran, pengadaan dan berbaikan sarana dan prasarana pendidikan, dan meningkatkan manajemen sekolah (Ardiana, 2017: 15). Oleh karena itu, sekolah harus memperhatikan berbagai unsur di dalam pengembangan kualitas pendidikan. Pencapaian tujuan sekolah sangat tergantung pada komponen-komponen antara lain: kepala sekolah, karyawan tata usaha, siswa, masyarakat serta sarana dan prasarana serta guru (Simanjuntak, 2013: 18). Guru sebagai pelaksana pendidikan memegang peranan penting dan strategis dalam penentuan tercapainya tujuan pembelajaran. Guru menjadi salah satu faktor yang dapat menentukan tinggi rendahnya kualitas hasil pendidikan. Guru bertugas untuk meningkatkan pencapaian dan memberikan pengalaman pendidikan yang berkualitas untuk semua siswa. Hal ini berarti bahwa kualitas guru adalah faktor paling penting di sekolah yang dapat mempengaruhi prestasi siswa (Elliot, 2015: 103).

Widyastuti dan Yulianto (2018: 16) dalam penelitiannya menyatakan bahwa terdapat 655.064 guru dari 2.838 .846 guru atau $(23,07 \%)$ bahwa guru yang mengajar belum memiliki standar kualifikasi tamat D4 atau S1, hal ini berarti kinerja guru 
masih belum sesuai dengan harapan dalam menjalankan perannya sebagai pendidik profesional. Guru harus mempunyai kinerja yang dapat mengoptimalkan dan merealisasikan keinginan dan harapan berbagai pihak dan guru dalam membina siswa di sekolah (Sucriah, 2018: 99). Guru bertanggung jawab menyampaikan pelajaran, tetapi guru juga diharapkan dapat menciptakan suasana belajar yang menyenangkan, sehingga dalam upaya mewujudkan, salah satunya adalah dengan meningkatkan motivasi berprestasi guru. Guru dituntut untuk untuk memberikan pelayanan kepada peserta didik dengan 1;ebih baik. Faktor penting yang menunjang guru untuk bekerja dengan sebaik-baiknya yaitu motivasi berprestasi guru, jika guru termotivasi untuk berprestasi maka guru akan bekerja dengan penuh semangat dan bertanggung jawab, sedangkan apabila guru mempunyai motivasi berprestasi yang rendah maka akan timbul gejala seperti kemangkiran, malas bekerja, banyaknya keluhan guru, rendahnya prestasi kerja, rendahnya kualitas pengajaran, indisipliner guru dan gejala negatif lainnya (Ghufron, 2016: 256) Jika motivasi berprestasi guru menurun, maka tugas dan tanggung jawab guru tidak terlaksana dengan baik. Kondisi ini akan berdampak terhadap kelancaran proses belajar mengajar, oleh karena itu motivasi berprestasi guru mempunyai peranan yang penting dalam mencapai tujuan pendidikan. Faktor yang berpengaruh dalam mempengaruhi motivasi berprestasi guru diperoleh dari faktor intrinsik dan faktor ekstrinsik. (Sinarmata, 2014: 655).

Berdasarkan hasil observasi awal terhadap guru SD Negeri Se-Kecamatan Susukan diketahui bahwa gejala rendahnya motivasi berprestasi guru ditandai bahwa 1) beberapa guru tidak tepat waktu dalam bertugas, sebagian guru terlambat membuat perangkat pembelajaran, 2) Guru menggunakan metode pembelajaran yang monoton ketika proses belajar mengajar 3) Guru tidak kreatif dalam membina peserta didik dalam proses belajar mengajar 4) Guru kurang mempersiapkan perangkat kegiatan belajar mengajar 5) Guru jarang membuat artikel ilmiah 6) Guru tida aktif dalam kegiatan sekolah dengan alasan bukan bagian tugasnya ataupun karena kepala sekolah sudah menunjuk orang tertentu. Salah satu faktor dari luar yang berkontribusi dalam mempengaruhi motivasi berprestasi guru adalah peran kepala sekolah. Kepala Sekolah adalah pemimpin dalam pelaksanaan pendidikan yang merumuskan kebijakan sekolah. Kepala sekolah harus meningkatkan perannya secara maksimal memimpin sekolah dengan bijak dan terarah, serta mengarah kepada pencapaian tujuan sekolah. Kepala sekolah harus memiliki kepribadian yang baik, menjadi teladan guru dan memiliki kemampuan memotivasi bawahan guru, serta dapat berkomunikasi dengan baik. Nasrun (2016: 69) menyatakan bahwa peran kepala sekolah yang yang baik dapat digunakan untuk memotivasi guru untuk lebih berprestasi.

Kepala sekolah merupakan motor penggerak dalam upaya meningkatkan motivasi berprestasi guru sehingga kepala sekolah dituntut memiliki visi, misi serta wawasan luas mengingat perannya adalah sebagai pendidik, pemimpin dan administrator di sekolah (Suwignyo, dkk, 2013: 2). Mulyasa (2013: 98), kepala sekolah harus (a) meningkatkan kualitas pembelajaran yang dilakukan oleh para guru, (b) memberdayakan kerja guru di sekolah secara efektif dan efisien dan mendorong keterlibatan guru dalam setiap kegiatan di sekolah, (c) melaksanakan administrasi sekolah supaya tercipta situasi belajar mengajar yang baik (d) mensupervisi pekerjaan yang dilakukan oleh tenaga kependidikan. (e) memberikan petunjuk dan pengawasan, meningkatkan kemauan tenaga kependidikan, membuka komunikasi dua arah, dan mendelegasikan tugas. (f) harus mampu mencari, menemukan dan melaksanakan berbagai pembaharuan. Namun dalam kenyataannya, kepala sekolah dalam menjalankan tugas dan perannya belum maksimal karena merasa bahwa menjadi kepala sekolah hanya merupakan tugas tambahan selain tugas pokok sebagia guru. Wahyudi (2009: 63) menyatakan bahwa kenyataan tidak semua kepala sekolah memenuhi kriteria yang ditentukan, tetapi lebih mengutamakan pada golongan ataupun kepangkatan yang dijalani melalui masa kerja. Hasil observasi pendahuluan di SD Negeri Se-Kecamatan Susukan menunjukkan bahwa peran kepala sekolah sepenuhnya belum dapat dilaksanakan dengan baik. Beberapa peran yang belum optimal yaitu peran kepala sekolah sebagai edukator, manajer, leader dan motivator. Hal tersebut bisa dilihat dalam kepala sekolah memacu tercapainya hasilujian yang baik. Sebagian kepala sekolah di SD Negeri se-Kecamatan Susukan belum memiliki strategi yang sesuai untuk meningkatkan profesionalisme guru di sekolahnya. Hanya sebagian kepala sekolah yang memiliki kualifikasi manajerial yang baik. Kepala sekolah belum sepenuhnya dapat memperdayakan tenaga kependidikan dalam menunjang berbagai program. Sebagian kepala sekolah belum melaksanakan pengawasan secara maksimal untuk meningkatkan kinerja tenaga kependidikannya. Kepala sekolah selaku manajer dan motivator perlu menciptakan budaya kerja yang kondusif bagi guru maupun tenaga kependidikan. Penghargaan terhadap kinerja yang berupa pujian atau reward yang lain akan menambah motivasi berprestasi guru. Tidak seluruhnya kepala sekolah di SD Negeri se-Kecamatan Susukan melakukan hal tersebut karena berbagai alasan yang membuat guru kurang termotivasi untuk berprestasi. Maka dari itu selain faktor kepala sekolah, maka faktor budaya kerja juga dapat berpengaruh terhadap motivasi berprestasi guru.

Sekolah sebagai bagian dari organisasi khususnya di bidang pendidikan tentunya memiliki asumsi dasar, nilai-nilai di dalamnya yang melekat sebagai budaya kerja yang telah ada sejak lama. Budaya kerja merupakan perkembangan tentang nilainilai bersama dalam kehidupan organisasi dan mengikat semua orang dalam organisasi yang bersangkutan (Siagian 2010: 12). Budaya kerja akan menentukan apa yang boleh dan tidak boleh dilakukan oleh para anggota organisasi; menentukan batas-batas normatif perilaku anggota organisasi; menentukan sifat dan bentuk-bentuk pengendalian dan pengawasan organisasi; menentukan gaya Peran Kepala Sekolah yang dapat diterima oleh para anggota organisasi dan menentukan cara-cara kerja yang tepat. Budaya kerja di sekolah dapat menggambarkan tentang nilai dasar yang harus dilaksanakan oleh guru dalam rangka membantu pelaksanaan kerja, dengan budaya kerja yang baik. Hubungan kerja antara guru, antara guru dengan kepala sekolah, guru dengan tenaga pendidikan lainnya serta antar dinas di lingkungannya dapat menjadi kondusif. Budaya kerja berkaitan erat dengan motivasi berprestasi sebab motivasi berprestasi akan dapat menciptakan suasana psikologis di dalam diri guru baik itu 
bersifat kenyamanan maupun ketidaknyamanan kerja. Apabila budaya kerja baik maka guru mempunyai motivasi berprestasi yang tinggi, mereka akan terdorong dan berusaha meningkatkan kemampuannya dalam merencanakan, melakasanakan, dan mengevaluasi kurikulum yang berlaku di sekolah sehingga memperoleh hasil kerja yang maksimal. (Budhiarti, dkk, 2017: 3). Budaya kerja dapat merubah perilaku manusia dalam suatu kelompok untuk mencapai produktivitas kerja yang selalu mendasari nilai-nilai filosofi yang penuh makna, sehingga dapat menjadi motivasi, memberi inspirasi, untuk senantiasa bekerja lebih baik (Machwati dan Wibowo, 2015: 161).

Budaya kerja yang berkembang di SD Negeri se-Kecamatan Susukan tidak begitu menunjukkan budaya kerja yang baik, diantaranya banyak guru yang datang ke sekolah tidak tepat waktu atau terlambat untuk datang ke sekolah. Hal ini disebabkan karena sistem absensi yang masih manual yaitu tanda tangan yang bisa dirapel setiap minggu atau setiap bulan sehingga para guru tidak terbebani jadwal absen yang dibatasi oleh waktu. Jadwal pulang yang juga seenaknya sendiri tanpa memperhatikan peraturan pemerintah yang menyatakan jumlah 37,5 jam guru berada di sekolah. Indikasi lain adalah kurang baiknya administrasi pembelajaran yang dimiliki oleh para guru yang hanya copy paste dari tahun sebelumnya atau dari sekolah lain. Tidak semua guru SD se-Kecamatan Susukan membuat atau mengembangkan media pembelajaran yang memudahkan siswa untuk menangkap pelajaran yang diberikan serta gaya mengajar yang cenderung monoton tanpa variasi.

\section{METODE PENELITIAN}

Penelitian ini mengunakan pendekatan kuantitatif. Metode korelasional adalah metode yang menggunakan atau melibatkan hubungan satu variabel (X ) atau lebih terhadap satu variabel lain (Y). Peran kepala sekolah $\left(\mathrm{X}_{1}\right)$, Budaya kerja $\left(\mathrm{X}_{2}\right)$, dan motivasi berprestasi guru (Y).Populasi penelitian ini guru Sekolah Dasar Negeri Se-Kecamatan Susukan Kabupaten Semarang yang berjumlah 269 guru yang tersebar pada 26 sekolah. Sampel sebanyak 161 yang di tetapkan dengan rumus Slovin (Sugiyono, 2014:116), untuk setiap sekolah, sampel dipilih menggunakan teknik proporsiaonal random sampling.

Uji validitas instrument menggunakan korelasi product moment dengan ketentuan jika r-hitung $\geq$ r-tabel (0.30) (Sugiyono, 2014: 172). Uji reliabilitas dengan menggunakan Alpha Croncabch dengan ambang batas dilihat dari nilai lebih besar nilai $r$ tabel maka bisa dikatakan reliabel, jika nilai $\quad r>0,70$ (Riduwan, 2012: 111). Hasil uji reliabilitas adalah sebagai berikut:

Tabel 1. Hasil Uji Reliabilitas

\begin{tabular}{lccc}
\hline \multicolumn{1}{c}{ Variabel } & Cronbach Alpha & Batas Ambang & Kesimpulan \\
\hline Peran Kepala Sekolah & 0,912 & 0,70 & Reliabel \\
\hline Budaya Kerja & 0,910 & 0,70 & Reliabel \\
\hline Motivasi Berprestasi & 0,903 & 0,70 & Reliabel \\
\hline
\end{tabular}

Berdasarkan hasil uji reliabilitas diketahui peran kepala sekolah nilai cronbach alpha sebesar (0,912), budaya kerja $(0,910)$ dan motivasi berprestasi $(0,903)$ keseluruhan $>0,70$ sehingga dinyatakan reliabel.

\section{HASIL DAN PEMBAHASAN}

Hipotesis pertama, berdasarkan penghitungan data yang telah dilakukan diperoleh besaran koefisien korelasi product moment sebesar 0.590 atau $r_{\text {hitung }} 0.590>\mathrm{r}_{\text {tabel }} 0.153$ dan harga $\mathrm{p}=0.000<0.05$ untuk taraf signifikasi $5 \%$ sehingga kedua variabel $\mathrm{X}_{1}$ dan $\mathrm{Y}$ dapat dinyatak mempunyai korelasi sedang. Hasil koefisien determinasi untuk mengetahui besarnya pengaruh peran kepala sekolah terhadap motivasi berprestasi dapat dilihat pada tabel 2.

Tabel 2. Hasil Uji Pengaruh Peran Kepala Sekolah terhadap Motivasi Berprestasi

\begin{tabular}{ccccc}
\hline \multicolumn{5}{c}{ Model Summary } \\
\hline Model & $\mathrm{R}$ & R Square & $\begin{array}{c}\text { Adjusted R } \\
\text { Square }\end{array}$ & Std. Error of the Estimate \\
\hline 1 & $.590^{\mathrm{a}}$ & .348 & .344 & 8.65178 \\
\hline
\end{tabular}

Hasil nilai $R$ square sebesar 0.348 artinya bahwa 34,8\% motivasi berprestasi guru dipengaruhi oleh peran kepala sekolah, sisanya $65,2 \%$ dipengaruhi oleh variabel lain di luar model penelitian.

Berdasarkan tabel 3 hasil uji regresi peran kepala sekolah terhadap motivasi berprestasi diperoleh persamaan regresi sebagai berikut: $\hat{Y}=43,794+0.597 \mathrm{X}_{1}$. Koefisien regresi sebesar 0,597 menunjukkan koefisien regresi positif, artinya apabila peran kepala sekolah semakin baik maka motivasi berprestasi juga meningkat, demikian pula sebaliknya apabila peran kepala sekolah tidak baik, maka motivasi berprestasi guru juga akan mengalami penurunan. 
Tabel 3. Koefisien regresi variabel $\mathrm{X}_{1}$ terhadap $\mathrm{Y}$

\begin{tabular}{lrrrrrr}
\hline Model & \multicolumn{2}{c}{ Unstandardized Coefficients } & Standardized Coefficients & t & \multicolumn{1}{c}{ Sig. } \\
\cline { 2 - 5 } & \multicolumn{1}{c}{ B } & Std. Error & Beta & & \\
\hline (Constant) & 43.794 & 8.976 & & 4.879 & .000 \\
Peran Kepala Sekolah & .597 & .065 & & .590 & 9.220 & .000 \\
\hline
\end{tabular}

Uji hipotesis kedua berdasarkan penghitungan data yang telah dilakukan diperoleh besaran koefisien korelasi product moment sebesar 0.584 atau $r_{\text {hitung }} 0.584>\mathrm{r}_{\text {tabel }} 0.153$ dan harga $\mathrm{p}=0.000<0.05$ untuk taraf signifikasi $5 \%$ sehingga kedua variabel $\mathrm{X}_{2}$ dan $\mathrm{Y}$ tergolong ada hubungan yang signifikan dengan tingkat keeratan yang sedang. Selanjutnya untuk mengetahui hipotesis kedua diterima atau ditolak, maka dilihat hasil uji anova berikut

Tabel 4. Koefisien Determinasi Budaya Kerja terhadap Motivasi Berprestasi

\begin{tabular}{|c|c|c|c|c|}
\hline \multicolumn{5}{|c|}{ Model Summary } \\
\hline Model & $\mathrm{R}$ & R Square & Adjusted R Square & Std. Error of the Estimate \\
\hline 1 & $.584^{\mathrm{a}}$ & .341 & .337 & 8.70200 \\
\hline
\end{tabular}

Hasil nilai $R$ square sebesar 0.341 artinya bahwa 34,1\% motivasi berprestasi dipengaruhi oleh budaya kerja, sisanya $65,9 \%$ motivasi berprestasi guru dipengaruhi oleh variabel lain di luar model penelitian ini.

Tabel 5. Koefisien Regresi variabel $\mathrm{X}_{2}$ terhadap $\mathrm{Y}$

\begin{tabular}{|c|c|c|c|c|c|}
\hline \multirow[t]{2}{*}{ Model } & \multicolumn{2}{|c|}{ Unstandardized Coefficients } & Standardized Coefficients & \multirow[t]{2}{*}{$\mathrm{t}$} & \multirow[t]{2}{*}{ Sig. } \\
\hline & $\mathrm{B}$ & Std. Error & Beta & & \\
\hline (Constant) & 35.589 & 10.030 & & 3.548 & .001 \\
\hline Budaya Kerja & .743 & .082 & & 9.066 & .000 \\
\hline
\end{tabular}

Berdasarkan hasil uji regresi budaya kerja terhadap motivasi berprestasi diperoleh persamaan regresi sebagai berikut: $\hat{\mathrm{Y}}=$ $35,589+0.743 \mathrm{X}_{1}$. Koefisien regresi sebesar 0,743 menunjukkan koefisien regresi positif, artinya apabila budaya kerja semakin baik maka motivasi berprestasi juga meningkat. Uji hipotesis ketiga dalam penelitian ini yang berbunyi " terdapat pengaruh peran kepala sekolah dan budaya kerja terhadap motivasi berprestasi. Berdasarkan hasil uji regresi ganda diperoleh sebagaimana tabel 6

Tabel 6. Koefisien Determinasi Pengaruh Peran Kepala Sekolah dan Budaya Kerja terhadap Motivasi Berprestasi

\begin{tabular}{|c|c|c|c|c|}
\hline \multicolumn{5}{|c|}{ Model Summary } \\
\hline Model & $\mathrm{R}$ & R Square & Adjusted R Square & Std. Error of the Estimate \\
\hline 1 & $.674^{\mathrm{a}}$ & .455 & .448 & 7.93914 \\
\hline
\end{tabular}

Hasil nilai Adjusted $R$ square sebesar 0.448 artinya bahwa 44,8\% motivasi berprestasi dipengaruhi peran kepala sekolah dan budaya kerja, sisanya 55,2\% bahwa motivasi berprestasi juga dipengaruhi oleh variabel lain di luar model penelitian.

Tabel 7. Hasil Koefisien Regresi Linier Berganda

\begin{tabular}{llrrrrr}
\hline Model & \multicolumn{2}{c}{ Unstandardized Coefficients } & Standardized Coefficients & t & \multirow{2}{*}{ Sig. } \\
\cline { 2 - 5 } & \multicolumn{1}{c}{ B } & \multicolumn{1}{c}{ Std. Error } & Beta & & \\
\hline & 12.075 & 10.024 & & 1.205 & .230 \\
(Constant) & .399 & .069 & .394 & 5.747 & .000 \\
Peran Kepala Sekolah & .484 & .087 & .381 & 5.552 & .000 \\
Budaya Kerja & & &
\end{tabular}

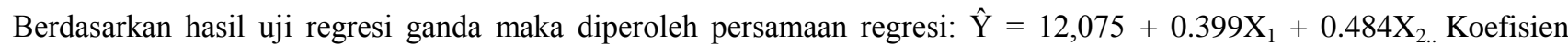
regresi variabel peran kepala sekolah sebesar 0,399 dan bernilai positif. Koefisien regresi variabel budaya kerja sebesar 0,484 dan bernilai positif, artinya apabila peran kepala sekolah dan budaya kerja semakin baik maka motivasi berprestasi guru juga meningkat, demikian pula sebaliknya.

\section{Pengaruh Peran Kepala Sekolah terhadap Motivasi Berprestasi Guru}

Kepala sekolah di SD se-Kecamatan Susukan Kabupaten Semarang sebagai pemimpin di sekolah harus mampu mendorong guru untuk memahami tujuan sekolah yang akan dicapai, memberikan kesempatan kepada guru untuk saling bertukar gagasan dalam memecahkan persoalan peserta didik. Kepala sekolah juga harus mampu membangkitkan semangat kerja guru, mampu menciptakan suasana kerja yang menyenangkan dan penuh semangat, mampu mengembangkan huru untuk bertumbuh dalam kepemimpinannya. Hal ini berarti bahwa kepala sekolah harus mampu membagi wewenang dalam 
pengambilan keputusan, sebab banyaklah tanggung jawab yang harus dilaksanakan kepala sekolah kepada setiap guru, sehingga dengan adanya pembagian tugas dan tanggung jawab yang baik dari kepala sekolah akan mampu meningkatkan motivasi berprestasi guru.

Hasil tersebut menunjukkan bahwa motivasi berprestasi guru dapat tumbuh dari dalam diri guru, karena rangsangan atau dorongan oleh adanyav unsur peran kepala sekolah. Kepala sekolah dapat memotivasi guru, staf dan speserta didik. Pola pendidik dengan pendekatan kemanusian melalui pembinaan nilai mental dan moral dalam hal yang berkaitan dengan kedisiplinan, kejujuran, tanggung jawab, bersahabat, luwes akan mempengaruhi motivasi berprestasi guru dan seluruh komponen sekolah untuk melaksanakan tugas sebaikbaiknya.

Berdasarkan hasil deskripsi penelitian diketahui bahwa peran kepala sekolah di SD se-Kecamatan Susukan Kabupaten Semarang termasuk dalam kategori cukup, sehingga dapat dikatakan sebagian besar guru SD se-Kecamatan Susukan Kabupaten Semarang berpendapat bahwa peran kepala sekolah di sekolah berada pada kondisi cukup baik. Indikator peran kepala sekolah yang kurang yaitu kepala sekolah kurang memberi kesempatan kepada guru untuk mengikuti pelatihan, sedangkan indikator peran kepala sekolah yang paling baik adalah kepala sekolah menyusun jadwal supervisi. Berdasarkan hal tersebut maka kesempatan guru untuk mengikuti pelatihan perlu lebih ditingkatkan lagi sedangkan untuk penyusunan jadwal supervisi yang dilakukan kepala sekolah perlu dipertahankan.

Dari hasil penelitian dapat diketahui bahwa korelasi antara peran kepala sekolah terhadap motivasi berprestasi sebesar 0,590 yang berarti terdapat hubungan yang signifikan peran kepala sekolah dengan motivasi berprestasi. Sedangkan besarnya pengaruh peran kepala sekolah terhadap motivasi berprestasi sebesar 34,8\% motivasi berprestasi dipengaruhi oleh peran kepala sekolah, sisanya 65,2\% ada pada variabel bebas lainnya yang mempengaruhi motivasi berprestasi selain variabel peran kepala sekolah. Persamaan regresi $\hat{Y}=43,794+0.597 \mathrm{X}_{1}$, maka dapat disimpulkan bahwa terdapat pengaruh positif dan signifikan peran kepala sekolah terhadap motivasi berprestasi. Hal ini juga berlaku sebaliknya yaitu jika peran kepala sekolah kurang baik maka akan juga menurunkan motivasi berprestasi guru.

Hasil penelitian ini sesuai dengan teori dari Nasrun (2016: 69) menyatakan bahwa peran kepala sekolah yang baik dapat digunakan untuk memotivasi guru dalam berprestasi. Kepala sekolah sebagai pendidik bertugas sebagai guru sehingga diharapkan dapat dijadikan contoh dan inspirasi para guru di sekolah. Kepala sekolah berperan menentukan dalam mengatasi dinamika organisasi sekolah dalam mencapai tujuan yang telah ditetapkan. Hasil penelitian ini sejalan dengan penelitian Suwignyo, Asrori, Sindju (2013) bahwa ada pengaruh yang peran kepala sekolah terhadap motivasi kerja guru Panatagama, Nurkolis, Akmal (2016) dalam penelitiannya juga menunjukkan bahwa peran kepala sekolah demokratis berpengaruh signifikan terhadap motivasi kerja guru.

\section{Pengaruh Budaya Kerja terhadap Motivasi Berprestasi Guru}

Budaya kerja berpengaruh signifikan terhadap motivasi berprestasi guru. Budaya kerja yang baik maka akan mampu memotivasi berprestasi guru untuk bekerja dengan lebih baik. Hal ini karena budaya kerja di sekolah dapat mengambarkan tentang nilai dasar yang harus dilaksanakan oleh guru dalam rangka membantu pelaksanaan kerja, dengan budaya kerja yang baik maka hubungan kerja antara guru, guru dengan kepala sekolah, guru dengan tenaga pendidikan lainnya dapat kondusif sehingga motivasi berprestasi juga menjadi lebih baik.

Motivasi berprestasi guru menjadi faktor penting, hal ini karena motivasi dapat mendukung perilaku guru untuk bekerja lebih giat dan antusias dalam mencapai hasil atau kualitas pendidikan yang lebih baik. Sebagai seorang guru, maka motivasi berprestasi merupakan energi yang dapat membangkitkan dorongan dari dalam diri guru tersebut dengan berdasarkan pada nilai-nilai sekolah yang ditetapkan berhubungan antara guru yang ada di sekolah untuk menentukan arah dan kebijakan yang berkaitan dengan tujuan sekolah yang ingin dicapai.

Guru di SD se-Kecamatan Susukan Kabupaten Semarang perlu mengenal tentang budaya kerja, karena budaya kerja dapat menjadi pedoman perilaku yang dalam melaksanakan aktivitas yang ada dalam sekolah, dimana tata tertib kerja yang merupakan bagian dari budaya kerja juga menjadi dasar bagi guru untuk meningkatkan motivasi berprestasi, misalnya adalah tentang pengaturan seragam dan jam kerja bagi guru. Berdasarkan hasil deskripsi penelitian diketahui bahwa budaya kerja di SD se-Kecamatan Susukan Kabupaten Semarang termasuk dalam kategori cukup, sehingga dapat dikatakan sebagian besar guru SD se-Kecamatan Susukan Kabupaten Semarang berpendapat bahwa budaya kerja di sekolah berada pada kondisi cukup baik. Indikator budaya kerja yang kurang yaitu bahwa guru kurang menyiapkan perangkat pembelajaran, sedangkan indikator budaya kerja yang paling baik adalah guru mengembangkan pengetahuan dengan belajar melalui internet.

Hasil penelitian dapat diketahui bahwa korelasi antara budaya kerja terhadap motivasi berprestasi sebesar 0,584 yang berarti terdapat pengaruh yang signifikan antara budaya kerja dengan motivasi berprestasi sebesar 34,1\% sisanya 65,9\% ada pada variabel bebas lainnya yang mempengaruhi motivasi berprestasi selain variabel budaya kerja dengan persamaan regresi sebagai berikut: $\hat{\mathrm{Y}}=35,589+0.743 \mathrm{X}_{1}$. maka dapat disimpulkan bahwa terdapat pengaruh positif dan signifikan budaya kerja terhadap motivasi berprestasi, maka semakin baik budaya kerja maka akan semakin meningkat motivasi berprestasi. Hal ini juga berlaku sebaliknya yaitu jika budaya kerja kurang baik maka akan juga menurunkan motivasi berprestasi guru.

Hasil penelitian ini sesuai dengan teori dari Budhiarti, dkk (2017: 3) bahwa budaya kerja dan motivasi kerja akan dapat menciptakan suasana psikologis di dalam diri guru baik itu bersifat kenyamanan maupun ketidaknyamanan kerja. Apabila budaya kerja baik maka guru mempunyai motivasi kerja inggi, guru terdorong dan berusaha meningkatkan kemampuannya 
dalam merencanakan, melakasanakan, dan mengevaluasi kurikulum yang berlaku disekolah sehingga memperoleh hasil kerja yang maksimal.

\section{Pengaruh Peran Kepala Sekolah dan Budaya Kerja terhadap Motivasi Berprestasi Guru}

Hasil menunjukkan bahwa peran kepala sekolah dan budaya kerja berpengaruh terhadap motivasi berprestasi. Peran kepala sekolah menjadi faktor yang dapat meningkatkan motivasi berprestasi guru. Selain itu budaya kerja juga menjadi aturan atau pedoman bagi guru dalam upaya meningkatkan motivasi berprestasi di dalam mengajar. Berdasarkan data penelitian dapat diketahui bahwa motivasi kerja guru SD se-Kecamatan Susukan Kabupaten Semarang termasuk dalam kategori cukup, sehingga dapat dikatakan sebagian besar guru berpendapat bahwa motivasi berprestasi sudah dimiliki guru dengan cukup baik. Indikator motivasi berprestasi yang paling rendah adalah guru jarang meminta saran dari kepala sekolah dalam pembelajaran, sedangkan indikator motivasi berprestasi yang paling tinggi adalah bahwa guru sebagai bagian dari masyarakat di wilayahnya masingmasing juga sering datang di acara pertemuan warga di rumah. Berdasarkan hal tersebut maka perlunya guru untuk meminta saran dari kepala sekolah apabila ada hal yang perlu ditanyakan serta mempertahankan aktivitas guru di dalam bersosialisasi dengan masyarakat di rumah.

Besarnya pengaruh peran kepala sekolah dan budaya kerja guru terhadap motivasi berprestasi guru sebesar 0.448 artinya bahwa 44,8\% motivasi berprestasi guru dipengaruhi oleh peran kepala sekolah dan budaya kerja, sisanya 55,2\% ada pada variabel bebas lainnya yang mempengaruhi motivasi berprestasi selain kedua variabel tersebut. Dengan persamaan regresi $\hat{\mathrm{Y}}=$ $12,075+0.399 \mathrm{X}_{1}+0.484 \mathrm{X}_{2}$. maka dapat disimpulkan bahwa terdapat pengaruh positif dan signifikan antara peran kepala sekolah dan budaya kerja guru terhadap motivasi berprestasi. Oleh karena itu dengan nilai koefisien regresi yang bertanda positif dan signifikan maka semakin baik peran kepala sekolah dan budaya kerja maka akan semakin meningkat motivasi berprestasi guru. Hal ini juga berlaku sebaliknya yaitu jika peran kepala sekolah dan budaya kerja kurang baik maka motivasi berprestasi guru juga akan mengalami penurunan.

Hasil penelitian ini sesuai dengan teori Sutrisno (2009: 111) bahwa motivasi memiliki komponen, yakni komponen dalam dan komponen luar. Jadi komponen dalam adalah kebutuhan-kebutuhan yang ingin dipuaskan, sedangkan komponen luar adalah tujuan yang hendak dicapai. Hal tersebut menunjukkan bahwa guru di SD se-Kecamatan Susukan Kabupaten Semarang perlu memahami faktor-faktor yang ada di dalam dirinya sendiri serta faktor yang berasal dari luar untuk dapat meningkatkan motivasi kerjanya demi terciptanya kualitas pendidikan yang lebih baik.

\section{SIMPULAN}

Peran kepala sekolah berpengaruh signifikan terhadap motivasi berprestasi guru SD se-Kecamatan Susukan Kabupaten Semarang sebesar 34,8\%, sisanya 65,2\% dipengaruhi variabel lainnya. Persamaan regresi $\hat{Y}=43,794+0.597 \mathrm{X}_{1}$. Budaya kerja berpengaruh signifikan terhadap motivasi berprestasi guru SD se-Kecamatan Susukan Kabupaten Semarang sebesar 34,1\% sisanya $65,9 \%$ dipengaruhi variabel lainnya Dengan persamaan regresi: $\hat{Y}=35,589+0.743 X_{2}$. Peran kepala sekolah dan budaya kerja berpengaruh signifikan terhadap motivasi berprestasi guru SD se-Kecamatan Susukan Kabupaten Semarang sebesar 44,8\% sisanya 55,2\% ada pada variabel bebas lainnya yang mempengaruhi motivasi berprestasi selain kedua variabel tersebut. Persamaan regresi $\hat{\mathrm{Y}}=12,075+0.399 \mathrm{X}_{1}+0.484 \mathrm{X}_{2}$. maka semakin baik peran kepala sekolah dan budaya kerja maka motivasi berprestasi guru juga semakin meningkat.

\section{REFERENSI}

Ardiana, TE. (2017). Pengaruh Motivasi Kerja Guru terhadap Kinerja Guru Akuntansi SMK di Kota Madiun. Jurnal Akuntansi dan Pajak. Vol. 17, No. 02, hal. 14-23.

Budhiarti, Y., Wahyudi., Sukmawati. (2017). Pengaruh Budaya Sekolah dan Motivasi Kerja terhadap Mutu Guru pada SMP Negeri di Kecamatan Sekayam. Jurnal Pendidikan dan Pembelajaran. Vol 6 No 2, hal 1-12.

Elliot, K. (2015). Teacher Performance Appraisal: More about Performance or Development ?. Australian Journal of Teacher Education. Vol 40 No 9, pp. 102-116.

Ghufron, MN. (2016). Kepuasan Kerja Guru PAUD Ditinjau dari Iklim Kelas dan Efikasi Mengajar. Quality. Vol 4 No 1, h. $254-270$.

Machwati, A dan Wibowo, UB. (2015). Pengaruh Budaya Kerja, Komitmen, Motivasi Kerja Guru Terhadap Iklim Organisasi $S D$. Jurnal Akuntabilitas Manajemen Pendidikan. Vol 3, No 2, hal 158-172.

Mulyasa, E. (2013). Menjadi Kepala Sekolah Profesional. Bandung : Remaja Rosdakarya.

Nasrun. (2016). Pengaruh Peran Kepala Sekolah Kepala Sekolah Terhadap Motivasi Kerja dan Kinerja Guru. Ilmu Pendidikan. Vol 1 No 2, hal 63-70.

Panatagama, Teguh, Nurkolis Nurkolis, Akmal Akmal. (2016). Pengaruh Gaya Kepemimpinan D Dan Supervisi Akademik Terhadap Motivasi Kerja Guru Madrasah Tsanawiyah Swasta Kabupaten Pati. Jurnal Manajemen Pendidikan (JMP).(5)3. DOI: http://dx.doi.org/10.26877/jmp.v5i3.1938 
Riduwan. (2012). Metode \& Teknik Menyusun Proposal Penelitian. Bandung: Alfabeta

Siagian, SP. (2010). Patologi Birokrasi, Analisis Identifikasi dan Terapinya Jakarta : Balai Aksara Yudistira Pustaka Saadyah.

Simanjuntak, THE. (2013). Pengaruh Budaya Organisasi, Peran Kepala Sekolah dan Kepuasan Kerja terhadap Komitmen Organisasi Guru SMK Sub Rayon 03 Pematang Siantar. Pelangi Pendidikan. Vol. 20 No. 1, hal. 17-28.

Sinarmata, Risda Herawati. (2014). Upaya Peningkatan Motivasi Kerja Guru Sekolah Dasar. Jurnal Administrasi Pendidikan. Vol 2 No 1, hal 654-660.

Sucriah. (2018). Pelaksanaan Supervisi Akademik Melalui Pengelolaan Sarana dan Prasarana dalam Meningkatkan Kinerja Guru. Jurnal Dedikasi Pendidikan. Vo. 2, No. 1, hal. 97-101.

Sugiyono. (2014). Metode Penelitian Pendidikan Pendekatan Kuantitatif, Kualitatif, dan R\&D. Bandung: Alfabeta.

Sutrisno, Edy. (2009). Manajemen Sumber Daya Manusia, Cetakan ke-1. Jakarta: Kencana Prenada Media Group.

Suwignyo, D., Asrori, M dan Sindju, HB. (2013). Pengaruh Peran Kepala Sekolah Sebagai Pendidik, Pemimpin dan Administrator terhadap Motivasi Kerja Guru SMP. Jurnal Pendidikan dan Pembelajaran. Vol 2 No 3, hal 1-12.

Wahyudi. (2009). Peran Kepala Sekolah Kepala Sekolah dalam Organisasi Pembelajar (Learning Organization). Bandung : Alfabeta.

Widyastuti, S dan Yulianto, A. (2018). Peran Mediasi Motivasi Kerja pada Pengaruh Sertifikasi Profesi dan Peran Kepala Sekolah Kepala Sekolah terhadap Kinerja Guru. Economic Education Analysis Journal. Vol 7 No 1, hal 15-28. 